At last it occured to me why they came, and on placing the carce on the floor the onslaught on the contents was a convincing ploof that $A$. panthera would never be naturalised at St. Pedro. I could adduce many other instances of the smelling and the "pciception of sound" (to phrase it), but will not intrude on your space.

British Consulate, Noumea, New Caledonia, April 26

P.S. Since writing the above $I$ named the subject to Pere Montrousier, the celebrated French naturalist so long. resident in this colony. He detailed the following experiment that he had made. He immersed a long-snouted weevil (Octhorinus cruciatus) so as to cover it, all but the tip of the antenna, with a coatins of wax. On presenting to it oil of turpentine it became violently excited and endeavoured to escape. Another now had the tips of its antenne only coated with the wax, and neither turpentine nor any other strong smelling substance at all affected it. He places the faculty of the "perception of sound " equally in the antennx. Since the discovery of the telephone who shall say to what extent these delicate organs can recognise the vibra. tions of the air? And after all, what is our own " perception of sound" but the appreciation of a vibration?

\section{On the Lichen Gonidia Question}

Trit morpholngical side of Schwendener's theory may be now regarded as fully proved. The opponents have confined themselves on the whole to $\grave{i}$ priori arguments, and of tiuse who have applied themselves t) carefully working out afresh the relations of hypha and gonidium, several, if not all, have been converted to the new views. No one can have much faith in the haphazard style of preparation and examination known, p.xp excellence, as the "lichenological." However, one or two points remain which have not as yet received much attention. These are the beautiful symmetry of the lichen as a whole, the rareness of the application of the hypha to the gonidium, and the generally healthy look of the gonidia themselves. All this contrasts greatly with what we find, as a rule, in the relations of parasitical fungus and host.

With regard to the first objection I may call attention to the equally beautiful and symmetrical forms we find in galls, such as the spangles of the oak, the rose bedeguar, and the exquisite rosettes of certain Dipterocarpece.

It is, however, well known that many of the lower fungi can build up their protoplasm and live perfectly, if in addition to the salts needed for the growth of all plants (including nitrates or ammonium salts), there be present a tartrate or sugar. Now the gonidia, like the algæ with which they correspond, excrete as a cell-wall a thick layer of gelatinous consistency but giving reactions which show it a form of cellulose. It is in contact with, or through this that the hypha ramifies, and from this it can take up the necessary complement of the nnineral food supplied by the substratum and medium. It can grow freely; and the gonidium, with its protoplasm intact, can go on growing as comfortably as the oyster infested by Clion'. P'erhaps like the oyster it may be stimulated to a more active secretion of eavelope, but its health is unimpaired. Hence, too, there is no physiological need for the hypha to come in contact with the gonidia, and the last argunent of the old school becomes untenable

Owens Collere, Manchester.

Marcus M. hartod

\section{The Phonograph}

IN experimenting lately with the phonograph it occurred to me to try whether, after a series of musical or articulate sounds have been recorded, other series could successively be superim. posed on the same tinfoil and reproduced. I found that if the instrument be simply reset to the starting-point, and sung or spoken to a second time, it will afterwards faithfully reproduce both series of sounds as though two persons were singing or speaking simultaneously, and by repeating the same process, a third and fourth voice may be added, or one or more instru. mental parts, all of which will be reproduced. This experiment forms a striking commentary on Helmholtz's theory of the mode in which the ear recognises different tones in a chaos of sound, by analysing the compound wave, which it receives, into its component simple vibrations. Here the aggregate impressions on the tin-foil produce, so to speak, a compound indentation capable of reproducing a wave of sound which the ear can resolve into the original constituents.

Temple

\section{Remarkable Form of Lightning}

DURING a thunderstorm on Sunday afternoon, August 24, 1873, I saw a flash of lightning here exactly answering to $\mathrm{Mr}$. Joule's description of "punctuation." The note of the storm in my diary says:- "Lightning and thunder very frequent but not violent. One flash, very netar, had the appearnuce of a chain of alternate links, and remained visible, I should think, for half a second, gradually fading out." This persistence was, no doubt, mainly an optical illusion, but it shows the definiteness of the form. The flash was from cloud to cloud, and followed a very sinuous line, as described by $\mathrm{Mr}$. Lawrence. Is not this what old books describe as "chain lightning?"

Branch Hill Lodge, Hampstead Heath, July 12

\section{B. WOODD SMITH}

\section{OUR NEW PROTECTORATE}

WE have only to do with politics in this journal in so far as they concern science; but without pronouncing any opinion on the wisdom of the action taken by our government in the Eastern question, it may not be amiss to say a few words from a scientific standpoint on the interesting territories which have just been brought into close relation with this country. To England the region included in Asiatic Turkey is in some respects the most interesting in the world. If not exactly the cradle of our family, there is good reason to believe that it is in close proximity to it ; and no doubt it was one of the pathways by which the early Aryans sought their way to Europe. Historically and prehistorically, for the student of religion and the student of science, Turkey in Asia possesses features of the highest interest, and we may hope that one result of our new connection will be that our very imperfect knowledge of it in its various aspects will be rapidly filled up. Its shores-the Black Sea on the North, the Ægean on the west, the Mediterranean on the south, and, may we say, the Euphrates and Tigris rivers on the east - teem with historical associations. A careful investigation of its mountains and valleys, its rivers and numerous salt lakes, would doubtless yield the geologist a rich harvest of results, bearing everywhere as they do unmistakable evidence of former powerful volcanic action.

Asiatic Turkey, in its five great divisions of Anatolia or Asia Minor, Armenia, Kurdistan, Mesopotamia, and Syria, may be regarded as a western extension of the great central Asian plateau, with its surface much broken up by mountain chains and isolated ranges. This great plateau narrows very considerably as it approaches the 'Turkish territory in Asia, but increases in elevation. Here begins the Alpine region of Persia with Kurdistan; here are the lakes Urumiyeh and Van, and the sources of the rivers Zab, Tigris, Aras, and Euphrates. The table-land is broken up into and replaced by mountains, which rise to a great height, and by elevated valleys between then. On the north-east of Tur'ey-in-Asia both the mountain-ranges and the table-iands are united in the compact mountainregion and high table-land of Armenia, the country to the west resembling Europe in structure rather than Eastern Asia. Physically there are four divisions of this region, corresponding nearly to the divisions referred to above. The first is the elevated and mountainous table-land of Armenia, which extends in the form of a triangle between the angles of the three seas-the Caspian, the Black Sea, and the Gulf of Alexandretta on the south. Its central plain, on which stands Erzeroum, about which so mucb has recently been heard, rises to 7,000 feet above sealevel, and the highest peak of Ararat rises to above 17,000 feet.

The second great division is formed by the Caucasus, which is beyond the range of our present subject. The third separate mass is formed by the peninsula of Ana. tolia, or Asia-Minor, in the interior, a table-land of an average height of $3, \infty 0$ feet, and joined to Persia by the mountain-chain of the Taurus. The Syrian mountains 